\title{
Penentuan Lokasi Fasilitas Kesehatan Strategis Menggunakan Metode Naive Bayes pada RSU Bintang
}

\author{
Aniek Suryanti Kusuma*, Welda**, I Komang Juliana*** \\ * Teknik Informatika, STMIK STIKOM Indonesia \\ ** Teknik Informatika, STMIK STIKOM Indonesia \\ *** Teknik Informatika, STMIK STIKOM Indonesia \\ *anieksuryanti@stiki-indonesia.ac.id,**welda@stiki-indonesia.ac.id,***ikomangjuliana@gmail.com
}

\begin{abstract}
At present the selection of strategic health facility locations is not easy, to determine the right location and in accordance with the needs of patients must use the right calculation. Bintang General Hospital (RSU Bintang) has difficulties in determining the strategic location of new health facilities. The difficulty is due to the absence of data processing from the current system so that in determining the location of strategic health facilities is not based on data that has been analyzed. Based on the problems experienced by RSU Bintang and to assist in making a decision in establishing a strategic health facility location, a study was made to design a decision support system that can perform calculations to determine the location of the most strategic health facility with the title "Decision Support System. Determining the Location of Strategic Health Facilities Using the Naive Bayes Method at RSU Bintang". Decision support system that is built will have several functions, such as processing patient register data, user data processing, alternative location data processing, criteria data processing, data processing rules, Naive Bayes calculations and managing several reports that can be used as decision support for the RSU Bintang. in determining the location of the most strategic health facilities. In this system, testing has been done by using blackbox testing which gets the test results in accordance with the system design.
\end{abstract}

Keyword: Decision Support System, Naive Bayes, Bintang General Hospital

\section{Introduction}

RSU Bintang merupakan salah satu rumah sakit umum milik swasta yang berada di kabupaten Klungkung, tepatnya berlokasi di Jl. Ngurah Rai No. 10 Semarapura, Klungkung, Bali, Indonesia. RSU Bintang merupakan salah satu rumah sakit yang saat ini sudah menggunakan Sistem Informasi Rumah Sakit (SIMRS) dalam menjalankan operasionalnya. Sistem Informasi Rumah Sakit pada RSU Bintang diantaranya berguna untuk menyimpan data-data pasien yang berkunjung atau berobat di rumah sakit tersebut. Namun data-data yang ada pada Sistem Informasi Rumah Sakit tersebut belum dimanfaatkan atau belum dimaksimalkan untuk pengambilan keputusan bagi pihak manajemen dalam pengembangan Rumah Sakit di masa yang akan datang.

Kemajuan sistem informasi saat ini sudah semakin berkembang pesat di segala bidang kehidupan terutama dalam dunia kesehatan. Banyak sekali data yang dihasilkan oleh Sistem Informasi Rumah Sakit yang ada di RSU Bintang saat ini, mulai dari data pasien, data penyakit pasien serta riwayat kunjungan pasien. Namun, untuk dapat mengetahui informasi yang tersembunyi dari data-data tersebut, maka perlu dilakukan pengolahan terhadap data-data tersebut. Dalam penelitian ini akan dilakukan pengolahan data pasien yang berkunjung atau berobat di RSU Bintang. Hasil dari pengolahan data pasien ini bertujuan untuk membantu pihak manajemen RSU Bintang dalam menentukan fasilitas kesehatan baru yang strategis, untuk memudahkan pasien-pasien RSU Bintang untuk berobat serta sebagai upaya untuk mengembangkan rumah sakit itu sendiri.

Dalam rencana pengembangan RSU Bintang, terdapat rencana pembangunan fasilitas kesehatan baru yang dapat menjangkau pasien yang lebih banyak dan lebih baik. Namun manajemen masih mengalami kesulitan dalam menentukan lokasi-lokasi fasilitas kesehatan baru yang akan dibangun, dikarenakan belum ada cara dan tehnik yang dapat digunakan untuk memastikan lokasi mana yang dianggap strategis. Maka dari itu diperlukan suatu sistem yang dapat memperhitungkan segala kriteria yang mendukung dalam mengambil keputusan untuk menentukan lokasi fasilitas kesehatan yang strategis. Metode yang dipakai dalam pengambilan keputusan untuk menentukan lokasi fasilitas kesehatan ini adalah metode Naive Bayes. Metode Naive Bayes ini merupakan sebuah metode klasifikasi yang menggunakan metode probabilitas dan statistik[1]. Menurut Kusumadewi dalam [2] metode Naive Bayes memiliki kelebihan dengan kinerja yang baik dengan persentase hasil pengujian yang lebih tinggi. Dengan adanya sistem untuk menentukan lokasi fasilitas 
kesehatan strategis ini, diharapkan dapat mempermudah pihak manajemen RSU Bintang dalam menentukan lokasi fasilitas kesehatan baru yang strategis dan sesuai dengan kebutuhan pasien di daerah tersebut.

\subsection{Sistem Pendukung Keputusan}

Menurut Kurniasih, Sistem Pendukung Keputusan (SPK) adalah sebuah sistem yang mampu memberikan kemampuan pemecahan masalah maupun kemampuan pengkomunikasian untuk masalah dengan kondisi semi terstruktur dan tak terstruktur. Sistem ini digunakan untuk membantu pengambilan keputusan dalam situasi semi terstruktur dan situasi yang tidak terstruktur, di mana tak seorang pun tahu secara pasti bagaimana keputusan seharusnya dibuat[3]. Menurut Turban (2005), SPK dimaksudkan untuk menjadi alat bantu bagi para pengambil keputusan untuk memperluas kapabilitas mereka, namun tidak untuk menggantikan penilaian mereka. SPK ditujukan untuk keputusan-keputusan yang memerlukan penilaian atau keputusankeputusan yang sama sekali tidak dapat didukung oleh algoritma[4].

\subsection{Lokasi dan Fasilitas Kesehatan}

Lokasi adalah tempat di mana perusahaan harus bermarkas dan melakukan operasi. Jadi lokasi di sini adalah tempat di mana suatu jenis usaha atau bidang usaha akan dilaksanakan[5]. Dapat disimpulkan bahwa lokasi merupakan tempat yang ditentukan oleh suatu keputusan perusahaan/instansi untuk menjalankan kegiatan usaha atau kegiatan operasionalnya, dan mendistribusikan barang atau jasa yang menjadi kegiatan bisnisnya kepada konsumen (customer). Lokasi sangat penting bagi perusahaan atau pengusaha. Lokasi sangat mempengaruhi keputusan sasaran pasar dalam menentukan keputusannya.

\subsection{Naive Bayes}

Menurut Patil dan Sherekar[6], Naive Bayes merupakan sebuah pengklasifikasian probabilistik sederhana yang menghitung sekumpulan probabilitas dengan menjumlahkan frekuensi dan kombinasi nilai dari dataset yang diberikan. Algoritma mengunakan teorema Bayes dan mengasumsikan semua atribut independen atau tidak saling ketergantungan yang diberikan oleh nilai pada variabel kelas. Definisi lain mengatakan Naive Bayes merupakan pengklasifikasian dengan metode probabilitas dan statistik yang dikemukakan oleh ilmuwan Inggris Thomas Bayes, yaitu memprediksi peluang di masa depan berdasarkan pengalaman di masa sebelumnya[7]. Sedangkan menurut Prasetyo, Metode Naive Bayes adalah teknik prediksi berbasis probabilistic sederhana yang berdasar penerapan teorema Bayes (aturan Bayes) dengan asumsi independensi (ketidaktergantungan) yang kuat (naif). Metode ini menggunakan probabilitas bersyarat sebagai dasarnya. Pobabilitas X di dalam Y adalah probabilitas intereksi X dan $\mathrm{Y}$ dari probabilitas $\mathrm{Y}$, atau dengan kata lain $\mathrm{P}(\mathrm{X} \mid \mathrm{Y})$ adalah prosentase banyaknya $\mathrm{X}$ di dalam $\mathrm{Y}$. Metode Bayes ini merupakan metode yang baik di dalam mesin pembelajaran berdasarkan data training, dengan menggunakan probabilitas bersyarat sebagai dasarnya. Sedangkan kelemahan dari metode Naive Bayes adalah hanya bisa di gunakan untuk persoalan klasifikasi dengan supervised learning dan data - data kategorikal[8].

Secara umum, teorema Bayes dinyatakan sebagai:

$P(c \mid x)=\frac{P(x \mid c) P(c)}{P(x)}$

$P(c \mid X)=P\left(x_{1} \mid c\right) \times P\left(x_{2} \mid c\right) x \ldots \times P\left(x_{n} \mid c\right) \times P(c)$

Di mana:

$x \quad=$ data dengan class yang belum diketahui

$c \quad=$ hipotesis data $x$ merupakan suatu class spesifik

$P(c \mid x)=$ probabilitas hipotesis $c$ berdasar kondisi $x$ (posteriori probability)

$P(c) \quad=$ probabilitas hipotesis $c$ (prior probability)

$P(x \mid c)=$ probabilitas $x$ berdasarkan kondisi pada hipotesis $c$

$P(x) \quad=$ probabilitas dari $x$

\section{Research Method}

Dalam pengembangan sistem ini, metode yang digunakan adalah metode Waterfall. Model Waterfall adalah model klasik yang bersifat sistematis, berurutan dalam membangun software. Nama model ini sebenarnya adalah "Linear Sequential Model". Model ini sering disebut juga dengan "Classic Life Cycle" atau metode Waterfall[9]. Tahapan awal yang dilakukan adalah pengumpulan data dan analisis sistem yang berjalan yang dilakukan dengan wawancara dan observasi. Dilanjutkan dengan tahapan perencanaan dan pemodelan sistem dengan menganalisis hasil pengumpulan data dan perancangan sistem menggunakan Context Diagram, 
DFD, CDM dan PDM. Selanjutnya dilakukan tahap pembangunan dalam bentuk kode bahasa pemrograman PHP dan MySQL. Langkah terakhir adalah pengujian atas sistem yang telah dibangun menggunakan Blackbox Testing. Tahapan metode Waterfall dapat dilihat pada Gambar 1.

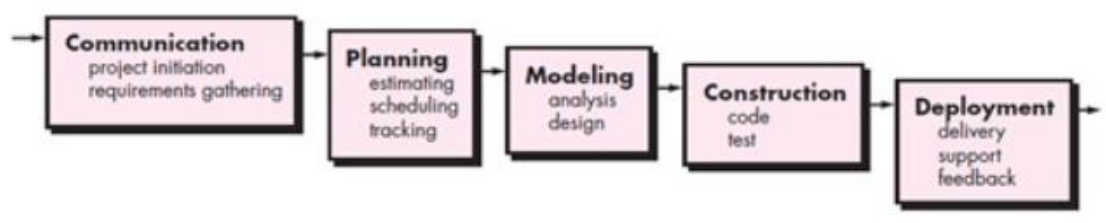

Gambar 1. Metode Waterfall

Sementara perhitungan untuk penentuan lokasi fasilitas kesehatan strategis pada penelitian ini menggunakan algoritma Naïve Bayes. Berikut ini flowchart perhitungan dengan algoritma Nä̈ve Bayes dapat dilihat pada Gambar 2 .

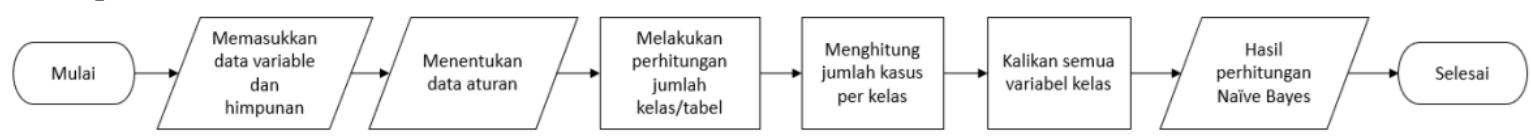

Gambar 2. Flowchart Algoritma Nä̈ve Bayes

Langkah-langkah algoritma naïve bayes adalah sebagai berikut:

1. Siapkan dataset.

2. Hitung jumlah kelas pada data training (data aturan).

3. Hitung jumlah kasus yang sama dengan kelas yang sama.

4. Kalikan semua hasil sesuai dengan data testing (data alternatif lokasi) yang akan dicari kelasnya.

5. Bandingkan hasil perkelas, nilai tertinggi ditetapkan sebagai kelas baru.

\section{Result and Analysis}

Analisis sistem adalah sebagai penguraian dari suatu sistem informasi yang utuh kedalam bagianbagian komponennya dengan maksud untuk mengidentifikasikan dan mengevaluasi permasalahanpermasalahan, kesempatan-kesempatan hambatan yang terjadi dan kebutuhan yang diharapkan sehingga dapat diusulkan perbaikan-perbaikannya.

\subsection{Analisis Sistem}

Analisis yang di lakukan dalam penelitian ini berdasarkan pegamatan atau kajian saat proses menentukan lokasi fasilitas kesehatan yang dilakukan oleh pihak manajemen RSU Bintang. Dalam penelitian ini kriteria yang digunakan yaitu jumlah pasien, luas lahan, harga sewa, dan jarak dengan jalan raya. Sistem yang dihasilkan akan dapat diakses oleh Admin dan Direktur Rumah Sakit.

Kebutuhan fungsional yang di butuhkan dalam perancangan sistem ini adalah:

1. Sistem harus memiliki keamanan hak akses yaitu login yang berfungsi untuk melindungi dan mendukung keamanan masing-masing halaman dari akses user yang tidak diperbolehkan.

2. Sistem harus dapat mengelola data pengguna (user) yang akan menggunakan sistem pendukung keputusan ini.

3. Sistem dapat mengimport data register pasien per kecamatan.

4. Sistem harus dapat mengelola data kriteria seperti manambah, mengubah, dan mencari.

5. Sistem harus dapat mengelola data sub kriteria seperti manambah, mengubah, dan mencari.

6. Sistem harus dapat mengelola data aturan seperti manambah, mengubah, dan mencari.

7. Sistem harus dapat mengelola data alternatif lokasi fasilitas kesehatan

8. Sistem harus dapat menampilkan hasil analisa lokasi fasilitas kesehatan yang strategis.

9. Sistem harus dapat menampilkan grafik lokasi fasilitas kesehatan yang strategis.

\subsection{Perhitungan Metode Naive Bayes}

Sebelum masuk pada perhitungan algoritma Nä̈ve Bayes terlebih dahulu menentukan kriteria yang akan dipakai untuk menentukan lokasi paling strategis. Penentuan Kriteria didapatkan dari hasil wawancara dengan Bapak I Gede Diki Sudrasana,S. KM selaku kepala SDM Tenaga Kesehatan masyarakat pada Rumah Sakit Umum Bintang

Tabel 1. Data Kriteria

\begin{tabular}{|l|l|}
\hline No & Nama Kriteria \\
\hline 1 & Jumlah Pasien \\
\hline
\end{tabular}




\begin{tabular}{|l|l|}
\hline 2 & Luas Lahan \\
\hline 3 & Harga Sewa (Per Tahun) \\
\hline 4 & Jarak dengan Jalan Raya \\
\hline
\end{tabular}

Tabel 2. Data Sub Kriteria

\begin{tabular}{|c|c|c|c|}
\hline No & Nama Sub Kriteria & Nilai & Keterangan \\
\hline \multirow[t]{3}{*}{1} & \multirow[t]{3}{*}{ Jumlah Pasien } & $<50$ & Sedikit \\
\hline & & $>=50 \mathrm{~s} / \mathrm{d}<=150$ & Sedang \\
\hline & & $>150$ & Banyak \\
\hline \multirow[t]{3}{*}{2} & \multirow[t]{3}{*}{ Luas Lahan } & $<50 \mathrm{~m}^{2}$ & Kecil \\
\hline & & $>=50 \mathrm{~m} 2 \mathrm{~s} / \mathrm{d}<=70 \mathrm{~m}^{2}$ & Sedang \\
\hline & & $>70 \mathrm{~m}^{2}$ & Luas \\
\hline \multirow[t]{3}{*}{3} & \multirow{3}{*}{$\begin{array}{lll}\begin{array}{l}\text { Harga } \\
\text { tahun) }\end{array} & \text { Sewa } & \text { (Per }\end{array}$} & $<25$ Juta & Murah \\
\hline & & $>=25$ Juta $\mathrm{s} / \mathrm{d}<=50$ Juta & Sedang \\
\hline & & $>50$ Juta & Mahal \\
\hline \multirow[t]{3}{*}{4} & \multirow{3}{*}{$\begin{array}{l}\text { Jarak dengan Jalan } \\
\text { Raya }\end{array}$} & $<1 \mathrm{~km}$ & Dekat \\
\hline & & $>=1 \mathrm{~km} \mathrm{~s} / \mathrm{d}<=2 \mathrm{~km}$ & Sedang \\
\hline & & $>2 \mathrm{~km}$ & Jauh \\
\hline
\end{tabular}

Sebagai contoh dalam perhitungan algoritma Nä̈ve Bayes berikut digunakan 27 data aturan yang sudah ditentukan oleh pihak rumah sakit umum bintang. Data aturan pada Tabel 3 merupakan data yang digunakan dalam penelitian ini dan data alternatif lokasi (data register pasien bulan Oktober) pada Tabel 4 data alternatif lokasi sebagai data testing pada perhitungan ini.

Tabel 3. Data Aturan

\begin{tabular}{|c|c|c|c|c|c|}
\hline No & $\begin{array}{l}\text { Harga } \\
\text { Sewa } \\
\text { (per } \\
\text { tahun) }\end{array}$ & $\begin{array}{c}\text { Jarak } \\
\text { dengan } \\
\text { Jalan } \\
\text { Raya } \\
\end{array}$ & $\begin{array}{l}\text { Jumlah } \\
\text { Pasien }\end{array}$ & Luas Lahan & Klasifikasi \\
\hline 1 & Mahal & Jauh & Banyak & Kecil & Tidak Strategis \\
\hline 2 & Sedang & Sedang & Banyak & Sedang & Strategis \\
\hline 3 & Murah & Dekat & Banyak & Luas & Strategis \\
\hline 4 & Sedang & Dekat & Banyak & Kecil & Strategis \\
\hline 5 & Murah & Jauh & Banyak & Sedang & Strategis \\
\hline 6 & Mahal & Sedang & Banyak & Luas & Strategis \\
\hline 7 & Murah & Sedang & Banyak & Kecil & Strategis \\
\hline 8 & Mahal & Dekat & Banyak & Sedang & Strategis \\
\hline 9 & Sedang & Jauh & Banyak & Luas & Strategis \\
\hline 10 & Murah & Dekat & Sedang & Kecil & Strategis \\
\hline 11 & Sedang & Sedang & Sedang & Sedang & Strategis \\
\hline 12 & Sedang & Jauh & Sedang & Luas & Strategis \\
\hline 13 & Mahal & Jauh & Sedang & Kecil & Tidak Strategis \\
\hline 14 & Murah & Dekat & Sedang & Sedang & Strategis \\
\hline 15 & Mahal & Sedang & Sedang & Luas & Strategis \\
\hline 16 & Sedang & Sedang & Sedang & Kecil & Strategis \\
\hline 17 & Mahal & Jauh & Sedang & Sedang & Tidak Strategis \\
\hline 18 & Murah & Dekat & Sedang & Luas & Strategis \\
\hline 19 & Mahal & Sedang & Sedikit & Kecil & Tidak Strategis \\
\hline 20 & Murah & Dekat & Sedikit & Sedang & Strategis \\
\hline 21 & Sedang & Jauh & Sedikit & Luas & Tidak Strategis \\
\hline 22 & Sedang & Jauh & Sedikit & Kecil & Tidak Strategis \\
\hline 23 & Mahal & Sedang & Sedikit & Sedang & Tidak Strategis \\
\hline 24 & Murah & Dekat & Sedikit & Luas & Strategis \\
\hline 25 & Murah & Dekat & Sedikit & Kecil & Tidak Strategis \\
\hline 26 & Sedang & Jauh & Sedikit & Sedang & Tidak Strategis \\
\hline 27 & Mahal & Sedang & Sedikit & Luas & Tidak Strategis \\
\hline
\end{tabular}

Tabel 4. Data Alternatif Lokasi

\begin{tabular}{|l|l|l|l|l|l|l|}
\hline No & Kecamatan & $\begin{array}{c}\text { Jumlah } \\
\text { Pasien }\end{array}$ & $\begin{array}{c}\text { Luas } \\
\text { Lahan }\end{array}$ & $\begin{array}{c}\text { Harga } \\
\text { Sewa }\end{array}$ & $\begin{array}{c}\text { Jarak } \\
\text { dengan } \\
\text { Jalan } \\
\text { Raya }\end{array}$ & Klasifikasi \\
\hline 1 & Banjarangkan & Banyak & Sedang & Sedang & Sedang & $?$ \\
\hline 2 & Sidemen & Banyak & Luas & Sedang & Dekat & $?$ \\
\hline
\end{tabular}




\begin{tabular}{|l|l|l|l|l|l|l}
\hline 3 & Karangasem & Sedang & Luas & Murah & Sedang & ?
\end{tabular}

Kemudian akan dilakukan perhitungan menggunakan metode Nä̈ve Bayes apakah data testing tersebut masuk dalam klasifikasi strategis atau tidak strategis. Berikut adalah hasil perhitungan Algoritma Naïve Bayes setelah dilakukan langkah-langkah perhitungan manual.

\section{Kecamatan Banjarangkan}

a. Definisikan dahulu fitur $x_{0}$ sampai $x_{n}$ untuk kecamatan Banjarangkan. Dimana $\mathrm{X}=($ Jumlah Pasien $=$ Banyak, Luas Lahan = Sedang, Harga Sewa $=$ Sedang, Jarak Dengan Jalan Raya $=$ Sedang $)$.

Kemudian kita hitung nilai probabilitas klasifikasi untuk semua data aturan yang ada.

Jumlah Klasifikasi Strategis $=17$

Jumlah Klasifikasi Tidak Strategis $=10$

Maka,

$\mathrm{P}($ Klasifikasi="Strategis" $)=17 / 27=0.62962963$

$\mathrm{P}($ Klasifikasi="Tidak Strategis") $=10 / 27=0.37037037$

b. Selanjutnya hitung probabilitas tiap fitur yang terkait dengan kecamatan Banjarangkan terhadap klasifikasi. P(Jumlah Pasien="Banyak" | Klasifikasi="Strategis") = 8/17 = 0.470588235

$\mathrm{P}($ Jumlah Pasien="Banyak" | Klasifikasi="Tidak Strategis") $=1 / 10=0.1$

$\mathrm{P}($ Luas Lahan="Sedang" | Klasifikasi="Strategis") $=6 / 17=0.352941176$

P(Luas Lahan="Sedang" | Klasifikasi="Tidak Strategis") $=3 / 10=0.3$

$\mathrm{P}($ Harga Sewa ="Sedang" | Klasifikasi="Strategis") $=6 / 17=0.352941176$

$\mathrm{P}($ Harga Sewa="Sedang" | Klasifikasi="Tidak Strategis") $=3 / 10=0.3$

$\mathrm{P}($ Jarak dengan Jalan Raya="Sedang" | Klasifikasi="Strategis" $)=6 / 17=0.352941176$

$\mathrm{P}($ Jarak dengan Jalan Raya="Sedang" | Klasifikasi="Tidak Strategis" $)=3 / 10=0.3$

c. Langkah selanjutnya adalah hitung probabilitas $\mathrm{P}(\mathrm{X} \mid \mathrm{c})$.

$\mathrm{P}(\mathrm{X} \mid$ Klasifikasi="Strategis" $)=$

P(Jumlah Pasien="Banyak" | Klasifikasi="Strategis") x P(Luas Lahan="Sedang" | Klasifikasi="Strategis") x P(Harga Sewa ="Sedang" | Klasifikasi="Strategis") x P(Jarak dengan Jalan Raya="Sedang" | Klasifikasi="Strategis")

$=0.470588235 \times 0.352941176 \times 0.352941176 \times 0.352941176=0.020689407$

$\mathrm{P}(\mathrm{X} \mid$ Klasifikasi="Tidak Strategis" $)=$

$\mathrm{P}($ Jumlah Pasien="Banyak" | Klasifikasi="Tidak Strategis") X P(Luas Lahan="Sedang" | Klasifikasi="Tidak Strategis") x P(Harga Sewa="Sedang"| Klasifikasi="Tidak Strategis") x P(Jarak dengan Jalan Raya="Sedang" | Klasifikasi="Tidak Strategis")

$=0.1 \times 0.3 \times 0.3 \times 0.3=0.0027$

Kemudian hitung probababilitas $\mathrm{P}(\mathrm{c} \mid \mathrm{X})$

$\mathrm{P}($ Klasifikasi="Strategis" $\mid \mathrm{X})=\mathrm{P}(\mathrm{X} \mid$ Klasifikasi $=$ Strategis $) \times \mathrm{P}($ Klasifikasi $=$ Strategis $)$

$=0.020689407 \times 0.62962963=\mathbf{0 . 0 1 3 0 2 6 6 6 4}$

$\mathrm{P}($ Klasifikasi="Tidak Strategis" $\mid \mathrm{X})=\mathrm{P}(\mathrm{X} \mid$ Klasifikasi = Tidak Strategis $)$ x $\mathrm{P}($ Klasifikasi = Tidak Strategis $)$

$=0.0027 \times 0.37037037=\mathbf{0 . 0 0 1}$

d. Langkah terakhir bandingkan hasil per kelas

Dari perhitungan probabilitas strategis dan probabilitas tidak strategis pada langkah sebelumnya, dapat disimpulkan bahwa data Kecamatan Banjarangkan, Jumlah Pasien = Banyak, Luas Lahan = Sedang, Harga Sewa $=$ Sedang, Jarak Dengan Jalan Raya = Sedang, masuk ke dalam klasifikasi "Strategis" karena probabilitas strategis $\mathbf{( 0 . 0 1 3 0 2 6 6 6 4 )}$ lebih tinggi dibandingkan probabilitas tidak strategis (0.001).

\section{Kecamatan Sidemen}

Sesuai cara perhitungan pada Kecamatan Banjarangkan, maka berikut kesimpulan hasil perhitungan untuk kecamatan Sidemen sesuai dengan kondisi, Kriteria dan subkriteria pada alternatif Kecamatan Sidemen: Dari perhitungan probabilitas strategis dan probabilitas tidak strategis pada langkah sebelumnya, dapat disimpulkan bahwa data Kecamatan Sidemen, Jumlah Pasien = Banyak, Luas Lahan = Luas, Harga Sewa= Sedang, Jarak Dengan Jalan Raya = Dekat, masuk ke dalam klasifikasi "Strategis" karena probabilitas strategis (0.020264) lebih tinggi dibandingkan probabilitas tidak strategis $(\mathbf{0 . 0 0 0 2 2 2 2})$.

\section{Kecamatan Karangasem}

Sesuai cara perhitungan pada Kecamatan Banjarangkan, maka berikut kesimpulan hasil perhitungan untuk kecamatan Sidemen sesuai dengan kondisi, Kriteria dan subkriteria pada alternatif Kecamatan Sidemen: Dari perhitungan probabilitas strategis dan probabilitas tidak strategis pada langkah sebelumnya, dapat 
disimpulkan bahwa data Kecamatan Karangasem, Jumlah Pasien = Sedang, Luas Lahan = Luas, Harga Sewa = Murah, Jarak Dengan Jalan Raya = Sedang, masuk ke dalam klasifikasi "Strategis" karena probabilitas strategis (0.017730737) lebih tinggi dibandingkan probabilitas tidak strategis $(\mathbf{0 . 0 0 0 4 4 4 4 )}$.

Dari hasil perhitungan yang diperoleh, didapatkan dari ketiga data alternatif lokasi berada pada klasifikasi "Strategis". Sedangkan klasifikasi strategis dengan nilai probabilitas paling besar pada data testing (data alternatif lokasi) ada pada kecamatan "Sidemen".

\subsection{Perancangan Data Flow Diagram}

Data Flow Diagram (DFD) Level Nol (0) pada sistem pendukung keputusan menentukan lokasi fasilitas kesehatan strategis pada RSU Bintang dapat dilihat pada Gambar 3. Pada rancangan Data Flow Diagram (DFD) ini melibatkan Admin dan Direktur sebagai penggunanya. Admin bertugas mengelola data kriteria dan alternatif, sedangkan Direktur berperan sebagai pelaksana pengambilan keputusan yang akan memproses penilaian dan perhitungan keputusan.

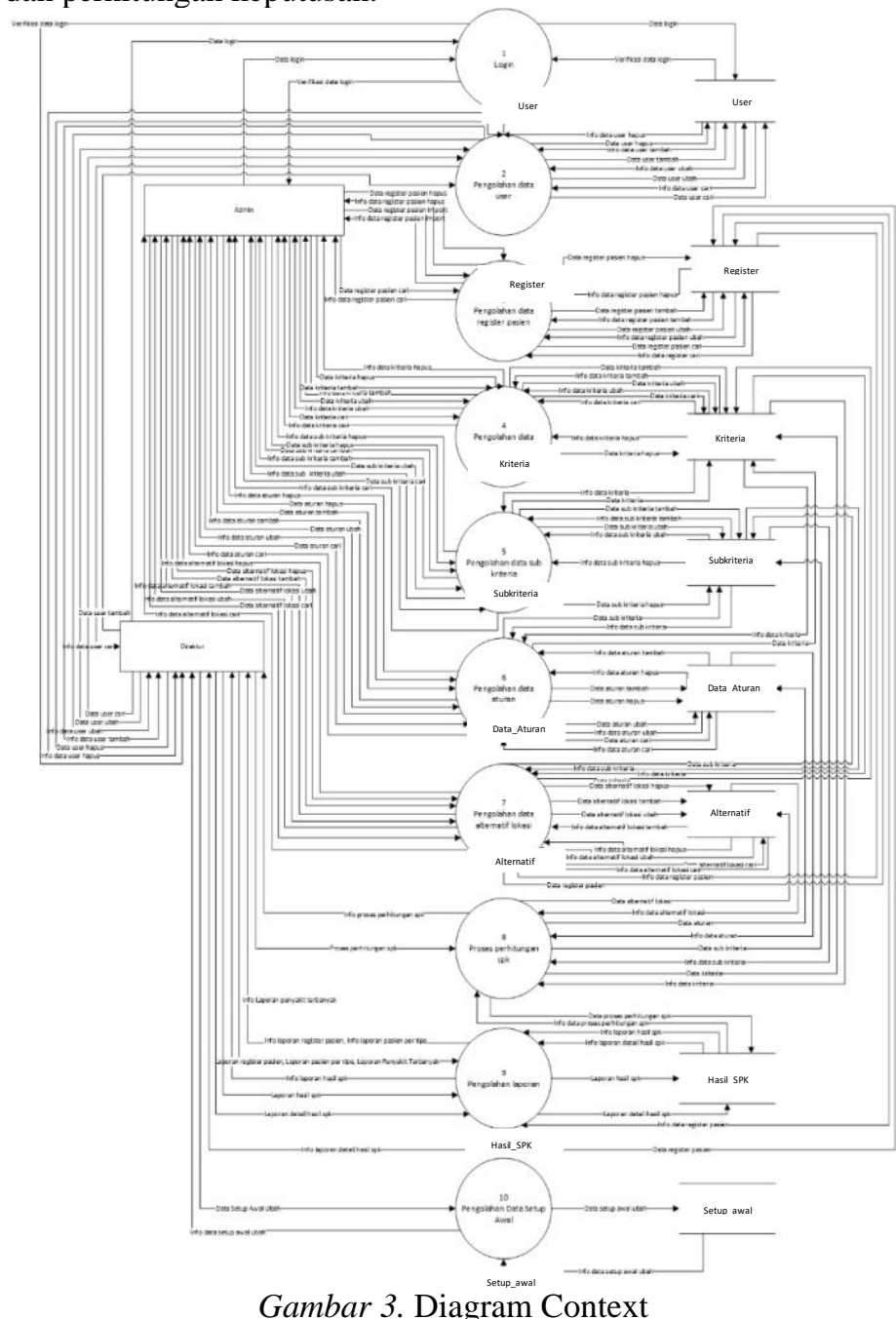

\subsection{Perancangan Data}

Conceptual Data Model dari perancangan sistem pendukung keputusan menentukan lokasi fasilitas kesehatan strategis menggunkaan metode Nä̈ve Bayes pada RSU bintang dapat dilihat pada Gambar 4. 


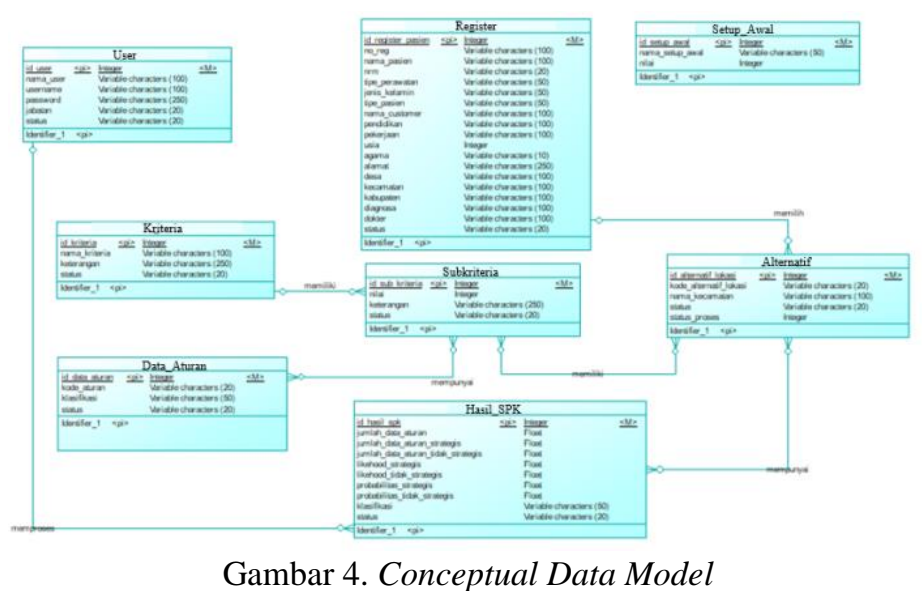

Physical Data Model dari perancangan sistem pendukung keputusan menentukan lokasi fasilitas kesehatan strategis menggunkaan metode nä̈ve bayes pada rsu bintang terdiri dari 11 tabel, yang terdiri dari tabel user, tabel register pasien, tabel data aturan, table detail data aturan, tabel kriteria, tabel sub kriteria, tabel alternatif lokasi, tabel detail alternatif lokasi, tabel hasil spk, tabel detail hasil spk dan tabel setup awal. Kardinalitas antar tabel dapat dilihat pada Gambar 5.

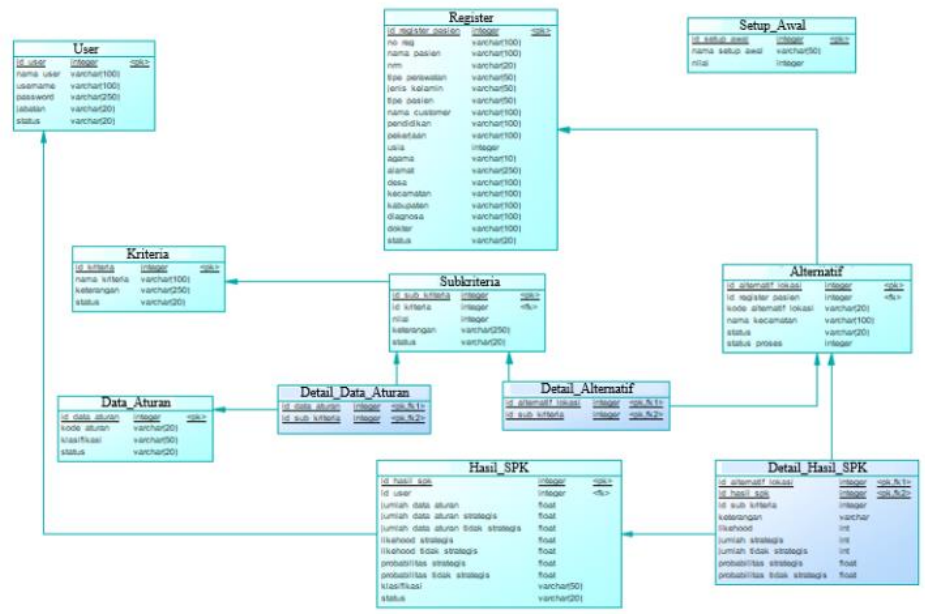

Gambar 5. Physical Data Model

\subsection{Implementasi}

Halaman dashboard admin seperti pada Gambar 6, menampilkan berapa banyaknya jumlah data, diantaranya jumlah data register pasien, data kriteria, data aturan, dan data alternatif lokasi serta profil dari RSU Bintang.

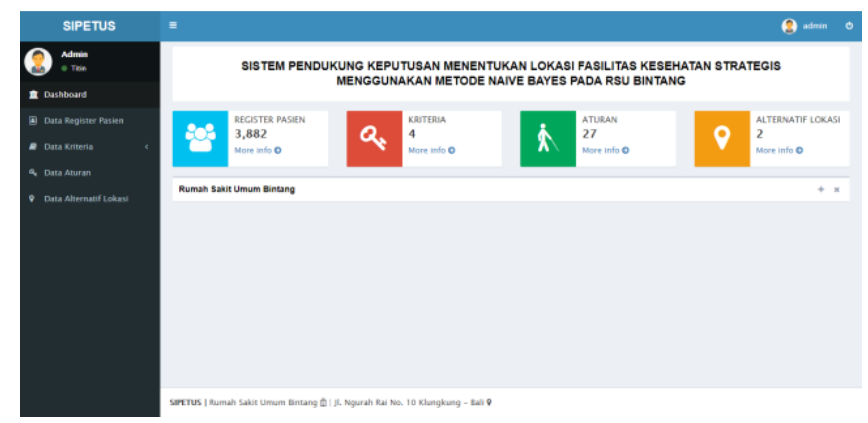

Gambar 6. Halaman Dashboard Admin

Halaman register pasien seperti pada Gambar 7, menampilkan data pasien yang sudah pernah berobat dan data tersebut di ambil dengan mengimpor data dari file excel yang sudah berisi data register pasien. Sedangkan halaman menu data kriteria seperti pada Gambar 8, menampilkan data kriteria yang terdiri dari harga sewa, jarak dengan jalan raya, jumlah pasien, dan luas lahan yang nantinya akan digunakan dalam perhitungan penentuan strategis atau tidaknya alternatif lokasi yang akan di proses. 


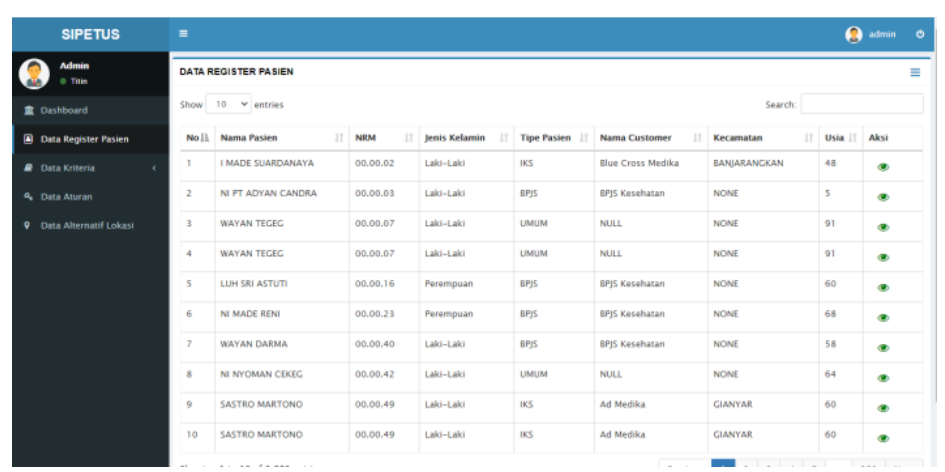

Gambar 7. Halaman Register Pasien

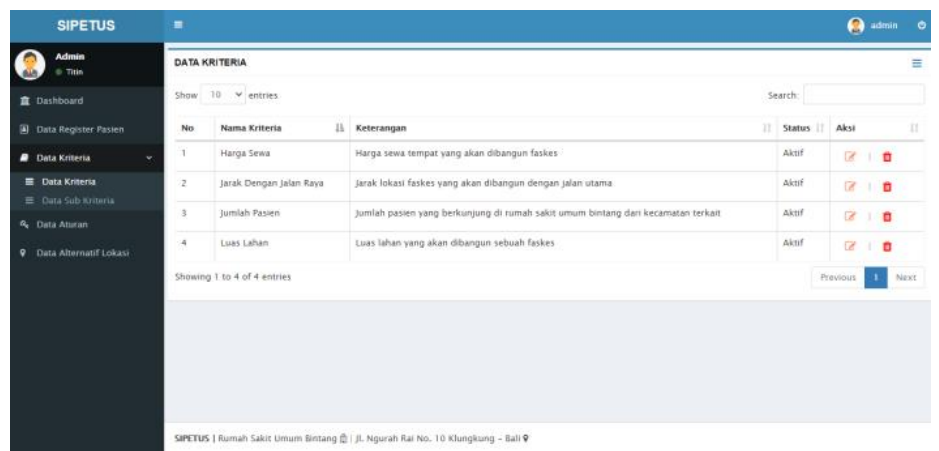

Gambar 8. Halaman Data Kriteria

Halaman proses SPK seperti pada Gambar 9, menampilkan tabel data alternatif lokasi yang akan diproses SPK yang terdiri dari kolom centang alternatif lokasi, nama kecamatan, jarak dengan jalan raya, jumlah pasien, dan luas lahan. Setelah di centang atau dipilih data yang ingin di proses maka bisa langsung klik tombol "proses SPK".

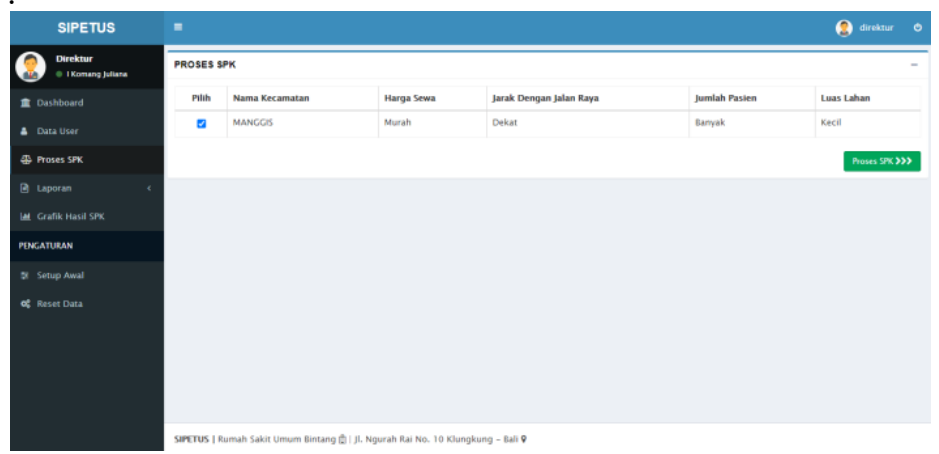

Gambar 9. Halaman Proses SPK

Halaman hasil SPK seperti pada Gambar 10, menampilkan hasil SPK dari proses perhitungan SPK yang telah dipilih di halaman sebelumnya. Dalam halaman hasil SPK ini dapat kita lihat perhitungan dan kesimpulan dari keputusan untuk menentukan strategis atau tidak strategisnya alternatif lokasi yang di pilih.
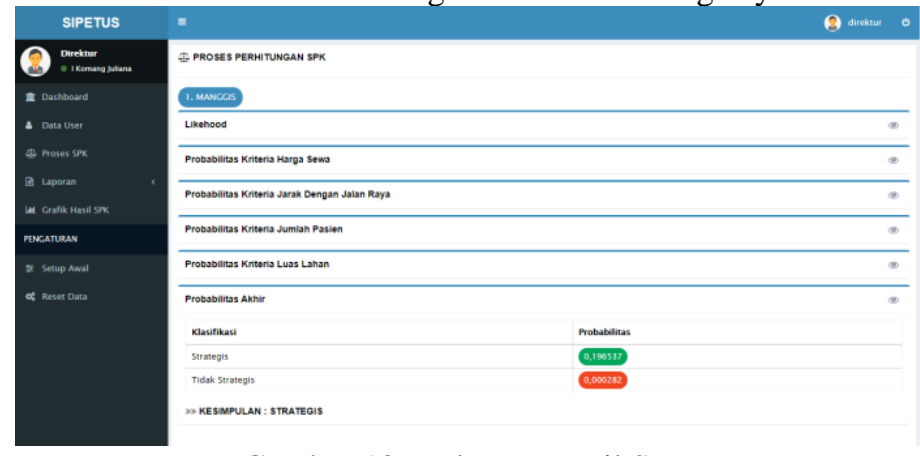

Gambar 10. Halaman Hasil SPK 


\subsection{Skenario Pengujian Sistem}

\subsubsection{Pengujian Algoritma Naïve Bayes}

Pada penelitian ini dilakukan pengujian dengan memasukkan nilai untuk setiap alternatif lokasi yang ditunjukkan pada tabel 4. Nilai yang dimasukkan untuk setiap alternatif adalah sebagai berikut:

1. Kecamatan Banjarangkan: Jumlah Pasien = Banyak, Luas Lahan = Sedang, Harga Sewa = Sedang, Jarak Dengan Jalan Raya $=$ Sedang

2. Kecamatan Sidemen: Jumlah Pasien $=$ Banyak, Luas Lahan $=$ Luas, Harga Sewa $=$ Sedang, Jarak Dengan Jalan Raya = Dekat

3. Kecamatan Karangasem: Jumlah Pasien $=$ Sedang, Luas Lahan = Luas, Harga Sewa = Murah, Jarak Dengan Jalan Raya $=$ Sedang

Maka didapatkan hasil klasifikasi strategis dan tidak strategis masing-masing alternative pada sistem sebagai berikut:

1. Kecamatan Banjarangkan $=$ Strategis $(0.013026664)$ dan tidak strategis $(0.001)$

2. Kecamatan Sidemen $=$ Strategis $(0.020264)$ dan tidak strategis $(0.0002222)$

3. Kecamatan Karangasem $=$ Strategis (0.017730737) dan tidak strategis (0.0004444)

Dengan demikian, dapat disimpulkan bahwa penerapan algoritma Naïve Bayes pada sistem yang dibangun telah sesuai dengan yang diharapkan.

\subsubsection{Pengujian Aplikasi}

Pengujian yang dilakukan pada halaman dashboard yaitu untuk mengetahui semua data yang ditampilkan di halaman dashboard sudah sesuai atau tidak.

Tabel 5. Pengujian Halaman Dashboard

\begin{tabular}{|l|l|l|l|l|}
\hline No & Form & Skenario & \multicolumn{1}{c|}{ Input } & \multicolumn{1}{c|}{ Hasil yang diharapkan } \\
\hline 1 & $\begin{array}{l}\text { Halaman } \\
\text { dashboard }\end{array}$ & $\begin{array}{l}\text { Menampilkan } \\
\text { halaman } \\
\text { dashboard }\end{array}$ & $\begin{array}{l}\text { User mengklik menu } \\
\text { dashboard }\end{array}$ & $\begin{array}{l}\text { Menampilkan dashboard yang } \\
\text { berisi data jumlah register pasien, } \\
\text { kriteria, aturan, dan alternatif lokasi } \\
\text { serta profil dari RSU Bintang }\end{array}$ \\
\hline
\end{tabular}

Pengujian yang dilakukan pada halaman data register pasien yaitu untuk mengetahui semua data yang ditampilkan pada halaman data register pasien sudah sesuai atau tidak dengan yang diharapkan.

Tabel 6. Pengujian Halaman Data Register Pasien

\begin{tabular}{|l|l|l|l|l|}
\hline No & Form & Skenario & \multicolumn{1}{c|}{ Input } & \multicolumn{1}{c|}{ Hasil yang diharapkan } \\
\hline \multirow{1}{*}{1} & $\begin{array}{l}\text { Halaman } \text { index } \\
\text { register pasien }\end{array}$ & $\begin{array}{l}\text { Menampilkan data } \\
\text { register pasien }\end{array}$ & $\begin{array}{l}\text { User memilih menu } \\
\text { register pasien }\end{array}$ & $\begin{array}{l}\text { Sistem menampilkan halaman data } \\
\text { register pasien }\end{array}$ \\
\cline { 3 - 5 } & $\begin{array}{l}\text { Import data } \\
\text { register pasien }\end{array}$ & Klik tombol import & $\begin{array}{l}\text { Sistem menampilkan pop up import } \\
\text { data }\end{array}$ \\
\cline { 3 - 5 } & $\begin{array}{l}\text { Melakukan } \\
\text { pengosongan data }\end{array}$ & $\begin{array}{l}\text { Klik tombol } \\
\text { kosongkan data }\end{array}$ & $\begin{array}{l}\text { Sistem menampilkan } \text { notifikasi } \text { setuju } \\
\text { atau tidak untuk melakukan } \\
\text { pengosongan data }\end{array}$ \\
\cline { 3 - 5 } & $\begin{array}{l}\text { Melihat detail data } \\
\text { register pasien }\end{array}$ & Tekan tombol detail & $\begin{array}{l}\text { Menampilkan modal detail data } \\
\text { register pasien }\end{array}$ \\
\hline
\end{tabular}

Pengujian yang dilakukan pada halaman data kriteria yaitu untuk mengetahui semua data yang ditampilkan pada halaman data kriteria sudah sesuai atau tidak dengan yang diharapkan.

Tabel 7. Pengujian Halaman Data Kriteria

\begin{tabular}{|l|l|l|l|l|}
\hline No & Form & Skenario & \multicolumn{1}{|c|}{ Input } & \multicolumn{1}{|c|}{ Hasil yang diharapkan } \\
\hline 1 & $\begin{array}{l}\text { Halaman } \text { index } \\
\text { data kriteria }\end{array}$ & $\begin{array}{l}\text { Menampilkan data } \\
\text { kriteria }\end{array}$ & $\begin{array}{l}\text { User memilih menu } \\
\text { kriteria }\end{array}$ & Sistem menampilkan data kriteia \\
\hline 2 & $\begin{array}{l}\text { Form tambah data } \\
\text { kriteria }\end{array}$ & $\begin{array}{l}\text { Menambah data } \\
\text { kriteria }\end{array}$ & $\begin{array}{l}\text { Semua field pada form } \\
\text { diisi dengan data yang } \\
\text { valid lalu klik simpan }\end{array}$ & $\begin{array}{l}\text { Data kriteria baru tersimpan ke } \\
\text { tabel kriteria }\end{array}$ \\
\cline { 2 - 4 } $\begin{array}{l}\text { Field tidak diisi atau } \\
\text { kosong }\end{array}$ & $\begin{array}{l}\text { Menampilkan pesan bahwa ada } \\
\text { field yang belum diisi }\end{array}$ \\
\hline 3 & $\begin{array}{l}\text { Form ubah data } \\
\text { kriteria }\end{array}$ & $\begin{array}{l}\text { Mengubah data } \\
\text { kriteria }\end{array}$ & $\begin{array}{l}\text { Semua field pada form } \\
\text { diisi dengan data yang } \\
\text { valid lalu tekan perbarui }\end{array}$ & $\begin{array}{l}\text { Data kriteria berubah pada tabel } \\
\text { kriteria }\end{array}$ \\
\hline 4 & $\begin{array}{l}\text { Halaman Hapus } \\
\text { data kriteria }\end{array}$ & $\begin{array}{l}\text { Menghapus data } \\
\text { kriteria }\end{array}$ & Klik tombol hapus & $\begin{array}{l}\text { Memunculkan notifikasi } \\
\text { persetujuan hapus }\end{array}$ \\
\hline
\end{tabular}


Pengujian yang dilakukan pada halaman proses SPK yaitu untuk mengetahui semua fitur yang ada pada halaman data alternatif lokasi sudah sesuai atau tidak dengan yang diharapkan.

Tabel 9. Pengujian Halaman Data Proses SPK

\begin{tabular}{|l|l|l|l|l|}
\hline No & Form & Skenario & \multicolumn{1}{c|}{ Input } & \multicolumn{1}{c|}{ Hasil yang diharapkan } \\
\hline 1 & Halaman proses & Proses SPK & $\begin{array}{l}\text { Centang alternatif lokasi } \\
\text { SPK } \\
\text { SPK }\end{array}$ & $\begin{array}{l}\text { Sistem melakukan perhitungan spk } \\
\text { dan menampilkan hasil perhitungan } \\
\text { Naive Bayes }\end{array}$ \\
\hline
\end{tabular}

Pengujian yang dilakukan pada halaman laporan hasil SPK yaitu untuk mengetahui data laporan yang ditampilkan pada halaman laporan hasil SPK sudah sesuai atau tidak dengan yang diharapkan.

Tabel 10. Pengujian Halaman Laporan Hasil SPK

\begin{tabular}{|l|l|l|l|l|}
\hline No & Form & Skenario & \multicolumn{1}{|c|}{ Input } & \multicolumn{1}{c|}{ Hasil yang diharapkan } \\
\hline 1 & $\begin{array}{l}\text { Halaman laporan } \\
\text { hasil spk }\end{array}$ & $\begin{array}{l}\text { Menampilkan } \\
\text { laporan hasil SPK }\end{array}$ & $\begin{array}{l}\text { Klik menu laporan hasil } \\
\text { SPK }\end{array}$ & $\begin{array}{l}\text { Sistem menampilkan data laporan } \\
\text { hasil SPK }\end{array}$ \\
\cline { 3 - 5 } & $\begin{array}{l}\text { Filter laporan hasil } \\
\text { SPK }\end{array}$ & Klik filter kecamatan & $\begin{array}{l}\text { Sistem menampilkan pop up pilihan } \\
\text { kecamatan }\end{array}$ \\
\cline { 3 - 5 } & $\begin{array}{l}\text { Mencetak laporan } \\
\text { hasil SPK }\end{array}$ & Klik tombol Cetak PDF & Sistem mencetak laporan hasil spk \\
\hline
\end{tabular}

\section{Conclusion}

Berdasarkan penelitian yang telah dilakukan dengan cara menganalisa, merancang dan membangun, dapat disimpulkan sebagai berikut:

1. Sistem Pendukung Keputusan Menentukan Lokasi Fasilitas Kesehatan Strategis Menggunakan Metode Naive Bayes Pada RSU Bintang ini dilakukan dengan pendekatan Data Flow Diagram (DFD) yaitu dengan menganalisis kebutuhan, Event List, Context Diagran, Data Flow Diagram Level 0, Data Flow Diagram Level 1 dan Entity Relationship Diagram (ERD) serta User Interface.

2. Proses implementasi pada pembuatan sistem ini menggunakan bahasa pemrograman PHP, framework Laravel, dan menggunakan DBMS MySQL.

3. Berdasarkan pengujian menggunakan Naïve Bayes, didapatkan bahwa klasifikasi strategis dengan nilai probabilitas paling besar pada data testing (data alternatif lokasi) ada pada kecamatan "Sidemen" dengan probabilitas strategis (0.020264).

4. Berdasarkan pengujian sistem menggunakan pengujian black box testing dapat disimpulkan bahwa aplikasi yang dibangun dapat menjalankan fungsinya sesuai dengan hasil yang diharapkan.

\section{References}

[1] N. P. C. Arnawati, S. K. Muchammad Naseer, and R. Hadi, "SISTEM PENDUKUNG KEPUTUSAN PEMILIHAN KARYAWAN TERBAIK PERPERIODE MENGGUNAKAN METODE NAIVE BAYES (STUDI KASUS: HOTEL INTERCONTINENTAL BALI RESORT )," JOSINFO J. Online Sist. Inf., vol. 1, no. 1, Aug. 2015, Accessed: Feb. 03, 2021. [Online]. Available: https://www.ejournal.stikombali.ac.id/index.php/josinfo/article/view/311.

[2] W. Muslehatin and M. Ibnu, "Penerapan Naïve Bayes Classification untuk Klasifikasi Tingkat Kemungkinan Obesitas Mahasiswa Sistem Informasi UIN Suska Riau,” May 2017. Accessed: Feb. 28, 2021. [Online]. Available: http://ejournal.uin-suska.ac.id/index.php/SNTIKI/article/view/3276.

[3] D. L. Kurniasih, "Sistem Pendukung Keputusan Pemilihan Laptop dengan Metode TOPSIS," Pelita Inform. Budi Darma, vol. III (April, 2013.

[4] N. Aeni Hidayah and E. Fetrina, "RANCANG BANGUN SISTEM PENDUKUNG KEPUTUSAN KENAIKAN JABATAN PEGAWAI DENGAN METODE PROFILE MATCHING (Studi Kasus: Kementerian Agama Kantor Wilayah DKI Jakarta),” Stud. Inform. J. Sist. Inf., vol. 10, no. 2, pp. 127-134, Oct. 2017, Accessed: Feb. 28, 2021. [Online]. Available: http://journal.uinjkt.ac.id/index.php/sisteminformasi/article/view/7760.

[5] R. Lupiyoadi, Manajemen Pemasaran Jasa. Jakarta: Salemba, 2013.

[6] T. R. Patil and M. S. S. Sherekar, "Performance Analysis of Naive Bayes and J48 Classification Algorithm for Data Classification,” Int. J. Comput. Sci. Appl., vol. 6, no. 2, 2013, Accessed: Mar. 28, 2021. [Online]. Available: http://www.cs.bme.hu/ kiskat/adatb/bank-data-.

[7] A. Saleh, "Implementasi Metode Klasifikasi Naïve Bayes Dalam Memprediksi Besarnya Penggunaan Listrik Rumah Tangga," Citec J., vol. 2, no. 3, pp. 207-217, 2015, Accessed: Feb. 03, 2021. [Online]. Available: https://citec.amikom.ac.id/main/index.php/citec/article/view/49.

[8] E. Prasetyo, Data mining konsep dan aplikasi menggunakan MATLAB - 2012. Yogyakarta: Andi Offset, 2012.

[9] R. . Pressman, Rekayasa Perangkat Lunak: Pendekatan Praktisi Buku I. Yogyakarta: Andi Offset, 2015. 